\title{
30 LAT Z „COLLECTANEA THEOLOGICA”
}

Upływa 30 lat od czasu, gdy w lecie 1990 r. objąłem funkcję redaktora naczelnego „Collectanea Theologica”, najstarszego naukowego czasopisma teologicznego w Polsce, którego wydawanie pod nazwą „Przegląd Teologiczny” zostało zapoczątkowane w 1920 r. we Lwowie. Przejęcie tej funkcji dokonało się po 20 latach jej sprawowania przez ks. prof. Henryka Bogackiego SJ, który nadał czasopismu nową witalność, dzięki której znacznie zwiększyła się siła i zasięg jego oddziaływania.

W okresie dwóch dekad (1970-1990), podczas których mój poprzednik sprawował funkcję redaktora naczelnego, na nim spoczywała praca polegająca na zbieraniu tekstów i podejmowaniu decyzji odnośnie do ich publikowania, a następnie ich opracowania redakcyjnego i przygotowania do druku, nadzorowania pierwszej i drugiej korekty oraz skierowania do drukarni. Przez trzy kolejne dekady nie było chętnych do włączenia się w systematyczną pracę, za którą nie przysługiwało żadne finansowe wynagrodzenie ani obniżka pensum dydaktycznego. Dlatego tym większa wdzięczność należy się redaktorom biuletynów, którzy - na tych samych zasadach - niestrudzenie zbierali i dostarczali nowe materiały. Ich personalia są regularnie zamieszczane na stronie redakcyjnej. Niektóre biuletyny przetrwały próbę czasu, inne przestały się ukazywać - wszystkie dokumentowały stan i rozwój różnych gałęzi teologii.

Co się tyczy artykułów, miałem stale w pamięci deklarację programową złożoną przez założycieli na łamach pierwszego numeru czasopisma: „Rzeczy wartościowe, oparte na badaniach gruntownych i sumiennych, znajdą u nas szczerych zwolenników; natomiast wszystko to, co nie ma wartości rzetelnej, spotka się z oceną taką, na jaką zasługuje swą treścią, a nie firmą pod jaką się ukaże. O ważną rzecz idzie! Przy niej, jak ruszymy, staną wraz z nami wszyscy, 
którzy polską naukę teologiczną chcą bogacić trwałemi pracami”. Nie wszyscy, którzy nadsyłali swoje teksty, doczekali się ich publikacji w „Collectanea Theologica”. Część autorów ze zrozumieniem przyjmowała trudną decyzję, zdarzali się jednak tacy, którzy nie potrafili się z nią pogodzić, a wtedy przychodziły na myśl słowa z nakreślonego przed stu laty Naszego programu: „Takie są nasze cele bliższe i dalsze. Innych nie mamy i mieć nie możemy tylko szczere i wyłącznie naukowe dla dobra ojczyzny naszej, a większej czci, znajomości i bojaźni Boga. Każdego, kto je uznaje, zapraszamy do współpracy i wzywamy do niej w imieniu tych, co po nas przyjdą i pytać będą: Coście nam zostawili?!...”"

Niniejszy numer czasopisma zawiera pięć retrospektywnych artykułów bilansujących stuletni dorobek „Collectanea Theologica” w zakresie biblistyki Starego i Nowego Testamentu oraz teologii dogmatycznej, teologii moralnej i duchowości. Zapoznanie się z tym dorobkiem pozwala rozpoznać zmiany pokoleniowe, przeobrażenia w uprawianiu teologii, a także najważniejsze kierunki i osiągnięcia opublikowanych prac badawczych. Takie są zręby odpowiedzi na pytanie postawione sto lat temu przez założycieli.

Patrząc na minione 30 lat, nasuwa się wiele obserwacji i wniosków, ale poprzestańmy na siedmiu.

Po pierwsze - w tym okresie następowały w Polsce radykalne zmiany społeczne i polityczne, które nie mogły ominąć nauki i życia akademickiego. W samych początkach, w 1990 r., została zlikwidowana uciążliwa państwowa cenzura książek i czasopism, która przez czas istnienia PRL-u była prawdziwą zmorą redaktorów, przeciągając i opóźniając prace nad wydawaniem publikacji. Pozostało ,imprimatur" kościelne, które z biegiem czasu uległo wyraźnemu rozluźnieniu. Przez kilka pierwszych lat głębokim przemianom ekonomicznym towarzyszyły niemałe kłopoty z zaopatrzeniem w należytej jakości papier i znalezieniem drukarni.

Po drugie - dokonała się ogromna, porównywalna jedynie z wynalezieniem i rozpowszechnieniem druku, rewolucji techniczna i technologiczna. Redakcje i autorzy stopniowo i nie bez ogromnych trudności przyzwyczajali się i przestawiali na nowe techniki 
informatyczne. Początkowo wszystkie nadsyłane teksty powstawały na tradycyjnych maszynach do pisania, po czym musiały być przepisane, żmudnie sprawdzane i przekazywane do dalszej obróbki redakcyjnej. Od połowy lat 90. coraz więcej tekstów napływało w wydruku komputerowym, na dyskietkach, a potem płytkach. Wynalezienie i rozpowszechnienie Internetu jeszcze bardziej uprościło i przyspieszyło drogę od biurka autora do gotowej publikacji.

Po trzecie - o ile do 1990 r. istniały tylko dwa uniwersyteckie wydziały teologiczne, na Katolickim Uniwersytecie Lubelskim i w Akademii Teologii Katolickiej w Warszawie, o tyle w następnych latach powstawały nowe - zarówno na uniwersytetach państwowych, jak i papieskich wydziałach teologicznych. Ambicją każdego stało się posiadanie własnego czasopisma, za czym szło zobowiązanie wykładowców do ogłaszania swoich prac we własnych środowiskach. Nie pozostało to bez wpływu na liczbę tekstów nadsyłanych do „Collectanea Theologica". Specyfika tego kwartalnika polega na tym, że ma profil ogólnopolski, a nie środowiskowy, co przesądza o jego randze i prestiżu.

Po czwarte - naukowy poziom zamieszczanych publikacji odzwierciedla aktualny stan i możliwości teologii polskiej. Dość powiedzieć, że z ogólnej liczby prawie tysiąca nadesłanych tekstów, około 10 proc. nie zostało zakwalifikowanych do druku. Zatem, oprócz tych, które zostały opublikowane, innych, lepszych, artykułów nie było. Co więcej, przegląd 120 numerów „Collectanea Theologica” wydanych w latach 1990-2020 pokazuje, że prawie $1 / 3$ to numery monotematyczne, zawierające materiały konferencji i sympozjów naukowych. Znaczy to, że gdyby ich nie było, niemożliwe okazałoby się regularne wydawanie kwartalnika z braku odpowiednich tekstów. Warto się zastanowić, czy da się to usprawiedliwić wyłącznie zwiększoną liczbą nowych wydziałów teologicznych i środowiskowych czasopism, czy też w grę wchodzą również inne, głębsze i poważniejsze przyczyny, wymagające rzetelnej i odważnej diagnozy.

Po piąte - wśród publikacji zamieszczonych w ostatnim trzydziestoleciu widać zwiększoną obecność publikacji biblijnych staroi nowotestamentowych. Ma to zapewne związek z osobą redaktora 
naczelnego, do którego chętniej i częściej bibliści nadsyłali swoje prace. Ale nie jest to jedyne, ani najważniejsze wytłumaczenie! Tekstów z innych dziedzin teologii po prostu nie było. Już w 1931 r. ks. Aleksy Klawek, ówczesny redaktor naczelny, wyrażał życzenie, „by równomiernie uwzględnione były wszystkie gałęzie wiedzy teologicznej". W ostatnich latach, w kontekście zalecanej przez ministerstwo i agendy państwowe punktokracji i powszechnie praktykowanej na uczelniach punktomanii, upowszechniło się nowe zjawisko: najpierw telefon z pytaniem: „Ile Collectanea ma punktów?”, po czym krótka rozmowa, a w niej brak zobowiązania redaktora do zamieszczenia tekstu, który miał być dopiero nadesłany, a potem brak kontaktu z potencjalnym autorem.

Po szóste - w latach 1975-1988 regularnie ukazywał się co roku „Fasciculus specialis” - numer obcojęzyczny. W toku gwałtownych przemian zabrakło jednak funduszów niezbędnych do kontynuowanie tej inicjatywy, w wyniku czego światło dzienne ujrzały tylko trzy numery z artykułami w językach obcych. Należałoby wrócić do dawnej praktyki i podjąć ją na nowo, ale nie to jest - i być może nie będzie - łatwe nie tylko z powodu niedostatku środków finansowych, lecz i braku odpowiedniej liczby wartościowych i godnych promowania artykułów. Dobrym wyjściem może być przetłumaczenie na angielski najlepszych artykułów opublikowanych w czasopiśmie po polsku i zamieszczenie ich w numerze obcojęzycznym.

Po siódme - ważną część czasopisma stanowią, obok artykułów i biuletynów, sprawozdania i recenzje. Paradoksalnie, dawniej, gdy liczba publikacji i dostęp do nich, zwłaszcza do publikacji zagranicznych, był o wiele trudniejszy, recenzji było znacznie więcej. Obecnie często są to teksty recenzji napisanych w przewodach i postępowaniach do uzyskania stopnia lub tytułu naukowego. Niedobór recenzji to niepokojące zjawisko, sugerujące, że czytelnictwo teologiczne przeżywa kryzys, zupełnie niezrozumiały i nie do zaakceptowania w środowiskach naukowych. Na osobną uwagę zasługuje sytuacja w seminariach duchownych i wśród duchowieństwa katolickiego w Polsce. Niegdyś, przed wojną i w okresie powojennym, istotne 
źródło utrzymania czasopisma stanowiła prenumerata, natomiast aktualnie nie ma ona większego znaczenia.

Wchodząc w drugie stulecie istnienia i oddziaływania, „Collectanea Theologica" staje wobec możliwości, wyzwań i trudności związanych z uprawianiem teologii w Polsce i z uprawianiem nauki w ogóle, zwłaszcza o profilu humanistycznym. Teologia katolicka powinna bardzo uważać, żeby nie została zredukowana do postnowoczesnej odmiany religioznawstwa czy religiologii. Takie zagrożenie pojawia się wtedy, kiedy coraz luźniejsza, a w końcu zupełnie zerwana, staje się jej więź z wiarą w Boga, który objawił siebie w Jezusie Chrystusie. Uprawianie teologii bez wiary jest jak pływanie w suchym basenie: naśladowanie ruchów nigdy nie sprawi takiej radości ani nie jest tym samym, co prawdziwe pływanie. Zdrowa teologia wyrasta z wiary i ma wiarę budować. We współczesnym świecie, w którym coraz modniejsza staje się dekonstrukcja prawdy i wszelkich wartości, powinnością teologii jest skuteczna obrona przed relatywizacją i subiektywizacją wiary i moralności, w wyniku czego człowiek traci mocny grunt, pogrążając się w zwątpieniu, zagubieniu i chaosie.

Pierwsze półrocze 2020 r. przyniosło radykalnie nowy kształt życia społecznego i religijnego. Świat został dotknięty pandemią koronawirusa. Jej rozmiary i skutki można porównać jedynie z najbardziej niszczycielskimi wybuchami zarazy, które dziesiątkowały i trapiły ludzi w minionych wiekach. Sytuacja narastającej globalizacji i atomizacji społeczeństwa zyskała nowe bodźce. Dzisiaj wiadomo, że świat nigdy nie będzie już taki sam, jak przed obecną pandemią. Czyni się bardzo dużo, aby przez zorganizowaną i skondensowaną (dez)informację jeszcze bezwzględniej sprawować władzę nad ludźmi i wszechstronnie nadzorować społeczeństwa, odrywając je od rodziny i pamięci, a także od tradycji narodowej i religijnej. Dlatego wiara w Boga oraz jej wyznawanie stanęły w obliczu wielkiej próby. W tych warunkach, bardziej niż kiedykolwiek, teologia staje się potrzebna, przede wszystkim po to, by udzielać odpowiedzi o charakterze najbardziej egzystencjalnym, respektujących najgłębsze przeznaczenie i sens ludzkiego życia. W trudnym czasie, gdy masowo podnosi się pytanie: „Jak przeżyć?”, tak samo natarczywie 
trzeba odpowiadać na odwieczne pytanie: „Jak żyć?” Codziennie mnożą się słuszne słowa wdzięczności dla personelu medycznego i pracowników służby zdrowia oraz służb społecznych za ofiarną pracę, poświęcenie i pomoc niesioną chorym i umierającym. W tej sytuacji wiara i teologia zdają, bądź nie, analogiczny egzamin. Nie sposób nie postawić pytania, czy wychodzą z niego zwycięsko, dając świadectwo prawdzie, że największą nędzą i przegraną jest choroba polegająca na usuwaniu Boga ze świata, który jest Jego dziełem oraz przedmiotem opatrznościowej opieki i troski.

Z dniem 1 lipca 2020 r., czyli od 3. tegorocznego numeru, funkcję redaktora naczelnego przejmuje ks. dr hab. Bartosz Adamczewski, profesor UKSW, któremu zawdzięczamy obecność kwartalnika od 2015 r. na platformie elektronicznej. Kończąc 30 lat pracy nad redagowaniem „Collectanea Theologica”, wyrażam serdeczne podziękowania wszystkim, którzy współuczestniczyli w tym wspaniałym dziele, cierpliwie i kompetentnie wzbogacając je swoją wiedzą i umiejętnościami. Następcy w sprawowaniu tej zaszczytnej funkcji życzę takiego poświęcenia i zapału, które pozwolą kontynuować i rozwijać zamysł założycieli, aby „,brać czynny udział w rozwijaniu i tłumaczeniu myśli Bożej, podanej w objawieniu, a strzeżonej przez nieomylny Kościół katolicki”. 